\title{
Inside the plant: Bacterial endophytes and abiotic stress alleviation
}

\author{
Pramod Kumar Pandey ${ }^{1,2^{*}}$, Siddhartha Singh ${ }^{2}$, Amit Kumar Singh², Ramkrishna Samanta ${ }^{3}$, \\ Raj Narain Singh Yadav ${ }^{3}$ and M. Chandrakumar Singh ${ }^{2}$
}

${ }^{1}$ Centre for Studies in Biotechnology, Dibrugarh University, Dibrugarh-786004 (Assam), INDIA

${ }^{2}$ Department of Basic Sciences \& Humanities, College of Horticulture \& Forestry, Central Agricultural University, Pasighat-791102 (Arunachal Pradesh), INDIA

${ }^{3}$ Department of Life Sciences, Dibrugarh University, Dibrugarh-786004 (Assam), INDIA

*Corresponding author. E-mail: pramod.pandey84@gmail.com

Received: March 6, 2016; Revised received: July 30, 2016; Accepted: October 26, 2016

\begin{abstract}
Bacterial endophytes are the microbes internally associated with the plant, nourished in an isolated environment which is free from the external harsh and changeable ecological condition. They entered into the plant tissues and alleviate the biotic and abiotic stresses by producing numerous secondary metabolites. They are engaged with the de novo synthesis of structural compounds and stimulation of plant immunity. They are also involved in the process of exclusion of the pathogen by niche competition and actively take part in phenylpropanoid metabolism. Abiotic stresses in particular salinity problem, low $\mathrm{pH}$, heavy metal toxicity and accumulation of recalcitrant complex compounds in the soil affecting the plant health are a major threat to the agriculture sector in crop production and stability of ecosystems. To cope with these problems agriculture productivity has been intensified by using synthetic chemicals and pesticides causes numerous problems worldwide. Endophytic bacteria are thus being utilized as a substitute to reduce the use of toxic chemicals and pesticides. They may be employed as a biological agent in the plant growth promotion and for the management of the global environment. There is a tremendous scope for the isolation and identification of new endophytic bacteria with excellent potential.
\end{abstract}

Keywords: Abiotic stress, Bioremediation, Endophyte, Endophytic bacteria, Salt stress

\section{INTRODUCTION}

Importance of microorganisms in human welfare have been ever realized from the ancient period of time in the dairy industry, fermentation industry, in biocontrol, production of antibiotics and up to more extent their utilization to produce novel bioactive compounds, secondary metabolites etc. (Bull, 2004). Their presence is noticed from various niches ranging from mountain to sea, from forest to desert and moreover, in cold and in hot spring also. In their various niches and unique places plants' inter-cellular space is one of them, which harbor vast variety and unnoticed group of microorganisms known as endophytes.

The term endophytic (endo- inside, phyte- plant) bacteria encompasses the internal association of bacteria with the plant (Hawksworth et al., 1995; Suto et al., 2002) and attributed various beneficial functions for the plant and the human welfare. They colonize the internal tissues of plants without any immediate negative or external symptoms. The study of endophytes may offer opportunities for discovering products and processes with potential applications in agriculture, industry, medicine, biotechnology and society. Endophytes can be found intracellularly either as obligate or in facultative association with lower and higher plants
(Pandey et al., 2013). History of exploitation of endophytes for their plentiful novel bioactive compounds were a century long, but very less progress was concerned towards bacterial endophytes which were found to be as a potential candidate as with other endophytic microorganisms like a fungus or more than them with their rapid multiplication, wide adaptability to variable environment, fast responses in various beneficial processes. Bacterial endophytes were reported to produce novel bioactive compounds which were not previously found to be reported naturally in plants such as insecticides (Ryan et al., 2008), antimicrobials (BacilioJimeÂnez et al., 2001; De Melo et al., 2009; Wang et al., 2009; Liu et al., 2010) etc. responsible for adaptation in variable environment, induction of immune response and restriction of pathogens invasion in plant tissues (Sturz et al., 2000; Lodewyckx et al., 2002; Pandey et al., 2015 and 2016), production of non- food crops for biomass and biofuel production (Rogers et al., 2012).

The present world faces problems caused by abiotic factors which could generate an alarming condition to the world's biomes. Research based on the invention of new inocula of endophytic bacteria is a promising task to cope with the adverse effect of abiotic factors. There is a strong need for the production of new metabolites and to search for the alternative pathway by 
utilizing endophytic bacteria which are effective but cause less or no damage to the environment and replace the artificial chemicals and pesticides. There is a tremendous scope for the isolation and identification of new endophytic bacteria with excellent potential. The current review summarizes the significance of using endophytic bacteria to nullify the adverse effect of abiotic factors, especially the problems related to salinity, the heavy metal toxicity and bioremediation. A brief attempt was made towards their progressive evolution, host variability and biodiversity.

History, origin and evolution of endophytes: Vogl in 1898 reported the presence of an endophytic mycelium inside the grass seed Lolium temulentum. Freeman in 1904 reported an endophytic fungus in annual grass Persian darnel. Bacterial endophytes have been studied for more than 100 years (Anu Ranjan, 2012). The first endophytic bacterial presence within the plant tissues was reported in 1926 (Hallman et al., 1997). Their relationship may have been thought to evolve during the hundred million years ago along with the higher plant appeared on the Earth (Anu Ranjan, 2012). It is found that certain microorganisms able to penetrate the plant tissues, either with the help of cell wall hydrolyzing enzymes like pectinease, cellulase or certain other mechanisms and reside inside the plant tissue and co-evolved. During co-evolution, they may be adapted towards the interior environment of the host plant involving the mechanisms of cross talk between the endophytes and the host plants (Pathak, 2011).

Host variability and biodiversity of the bacterial endophytes: Each individual plant on earth is host to one or several endophytes (Strobel et al., 2004; Ryan et al., 2008). Bacterial endophytes have been isolated from surface-sterilized plant tissues or extracted from internal plant tissues (James and Olivares, 1998). Strobel et al., (2004) reported that the total plant species reported i.e. approximately 300000 present on the earth, each plant species carry one or more endophytes in their lifetime and nearly all vascular plant species (wheat, rice, sugarcane, pea, tea, banyan tree etc.) investigated to date were reported to harbor endophytic bacteria (Pathak, 2011; Pandey et al., 2012; BacilioJimeÂnez et al., 2001; James and Olivares, 1998; Elvira-Recuenco \& Vuurde, 2000; Ratul et al., 2013; Jha et al., 2011). Their presence was also reported from different ecosystem such as from the copper mine wasteland, from agronomic and prairie plant's ecosystem, from deep water rice ecosystem, from grass ecosystem, from the pea field condition and from tropical grasses (Reinhold-Hurek \& Hurek, 1998; ElviraRecuenco \& Vuurde, 2000; Verma et al., 2001; Zinniel et al., 2002; Phillips et al., 2008; Sun et al., 2010; Kelemu et al., 2011).

Production of plant growth regulators (PGR): As we know hormones are organic compounds effective in very minute concentration, which after synthesis transported to another location where they interact with specific target tissue and regulate physiological functions such as division of cell, expansion of cell, differentiation, branching of shoot, cell death of the host plant and hence referred as plant growth regulators or Phyto-hormones (Auxins, Gibberellins, Ethylene, Cytokinins and Abscisic acid). Different endophytic bacterial groups like Bacillus species and Klebsiella species were reported to produce the indole-3acetic acid, the most important auxin which regulates plant development such as cell expansion, division, differentiation, gene regulation and other tropic response (Ratul et al., 2013; Ji et al., 2014). It is found that the concentration and ratio of auxin to other phyto -hormones determine the physiological responses inside the plant and the microorganism which was able to produce IAA positively regulate the auxin levels (Patten and Glick, 1996; Lambrecht et al., 2000). Cytokinins as another important phyto-hormone induce cell division of plant in combination with auxin. The ratio of high cytokinin to low auxin promotes shoot development, low cytokinin to high auxin ratio promotes root development and their equal concentration determines cell proliferation (callus formation) is the well known mechanism of action. Gibberellins are the phyto-hormone comprising terpenoids group consisting of up to 20 carbon atoms, but the GAs with 19 carbon atoms was found to be the most active. They are mainly involved in the cell division, cell elongation and participate in Internode elongation (Dodd et al., 2010). Abcisic Acid is a phyto- hormone with 15 carbon atoms actively involved in the biotic and abiotic stress response of plant such as drought stress, salt stress and metal toxicity. It is responsible for negative regulation of seed germination, flowering and opening of stomata during stress conditions (Smyth, 2011). Ethylene is a kind of gaseous phyto-hormone affects several plant developmental processes such as root hair formation, root growth, flowering and well known for inducing fruit ripening, flower senescence (Dugardeyn and van der Straeten, 2008; Dodd et al., 2010). They are also involved in breaking seed and bud dormancy. There are found to be synthesize in the response of various stress conditions such as in heat stress, in cold stress, in drought stress, in high levels of salt concentrations and in the case of excess heavy metals (Glick, 2005; Dodd et al., 2010), hence also called as the stress hormone.

Abiotic stress alleviation by bacterial endophytes: According to Food and Agriculture Organization, (2012) world's population will be 2.3 billion by 2050 result to rise in food production demand, which is possible only by increasing agricultural farmland and productivity, which is limited by several restrictions such as urbanization, water scarcity, phytopathogens, adverse effect and high cost value of synthetic fertilizers and pesticides. Hence, the alternatives for sustainable and secure agriculture have been in demand globally 
with grand promise in the improvement of agricultural yields. Sustainable agriculture contributes in national income as a major export earnings in today's developing countries as offering food security and employment to meet our future needs which conventional agriculture will not able to do.

According to an estimate more than $20 \%$ of agricultural soil faces increase in salinity problems (Zhu, 2000) and nearby $50 \%$ of the agriculturally important land will be affected by salinity stress by the year 2050 (Munns and Tester, 2008). Rising of salt concentrations in soil and irrigation water creates a key threat to agricultural scenario, which could be may manage by bacterial endophytes by osmotic adjustments, stomatal regulation, root morphology modification, increase in uptake of minerals and by reducing the toxic effects of $\mathrm{Na}^{+}$and $\mathrm{Cl}^{-}$(Sairam and Tyagi, 2004; Pandey et al., 2012).

Essential nutrients taken from plants by absorption of soluble salts stored in soil, but excessive accumulation of salts retarded the growth of plants (Patel et al., 2011). Problem of salinity is recognized as the major threats to environmental resources and human health affecting about 1 billion ha globally. According to an estimate in India about 9.38 million ha land occupied by saline soil (Metternicht and Zinck, 2003; Yensen, 2008; Patel et al., 2011; Misra and Dave, 2013). Efficient resource management and crop improvement can help to overcome salinity stress, but such approach being cost intensive and time taking. Hence, the use of microorganisms for exploitation of their unique properties such as synthesis of compatible solutes, tolerance to salinity and production of plant growth promoting hormones may be utilized for sustainable agriculture (Shrivastava and Kumar, 2015).

Heavy Metal toxicity is identified as one of the main abiotic stress factors that causes about $25-80 \%$ yield losses in various crop plants grown on soils (Singh et $a l ., 2011)$. Acidic soil engaged with poor crop productivity and low soil fertility due to the combined effect of Heavy Metal $\left(\mathrm{Al}^{+3}\right.$ and $\left.\mathrm{Mn}^{+2}\right)$ toxicities coupled with nutrient deficiencies ( $\mathrm{P}, \mathrm{Ca}, \mathrm{Mg}$ and $\mathrm{K}$ ) (Singh et $a l ., 2011)$. It is reported to highly toxic to plant roots (Kinraide, 1991) results in poor development of the root system (Foy, 1988; Singh et al., 2011). Heavy Metal toxicity became a serious problem which limits crop productivity on acidic soils. Endophytic bacteria are recognized as to take part in the mobilization and immobilization of metal cations, thereby, influences their availability to plants.

Endophytic bacteria found to be more active in inducing strong defense responses against stresses than the other rhizospheric or soil microbes (Andrews, 1992, Pandey et al., 2012). An endophytic bacterium Pseudomonas pseudoalcaligenes combined with a rhizospheric Bacillus pumilus in paddy were reported to protect the paddy plant from abiotic stress by induction of osmoprotectant and antioxidant proteins. At lower concentrations of salinity levels endophytic bacterium $P$. pseudoalcaligenes inoculated to the plants showed a considerable concentration of glycine betaine - like quaternary compounds and increase in shoot biomass. While a mixture of both $P$. pseudoalcaligenes and B. pumilus at higher salinity levels showed improved response against the adverse effects of salinity in the condition of Anand, Gujarat (Jha et al., 2011). Bacteria that produce exopolysaccharates (EPS) when inoculated with wheat seedlings influence the uptake of sodium and plant growth promotion in high stress of salinity (Grover et al., 2010).

A wheat endophytic bacterium (Pseudomonas aeruginosa PW09) was evaluated for its ability to alleviate abiotic stress in cucumber. PW09 culture was inoculated to cucumber seeds, and the seedlings were subjected to the high salt concentration $(\mathrm{NaCl} 150 \mathrm{~mm})$. Their role was evaluated in alleviating the stress by assessing plant biomass accumulation under $\mathrm{NaCl}$ stress as well as at the physiological level through phenylpropanoid metabolism, antioxidant activities and proline accumulation. The endophyte increased biomass accumulation significantly up to $18 \%$ under $\mathrm{NaCl}$ stress compared with endophyte-untreated seedlings. Application of PW09 also induced higher accumulation of proline (1.4-fold) and total phenolics (1.1fold) and activities of polyphenol oxidase (1.5-fold), phenylalanine ammonia lyase (1.27-fold) and superoxide dismutase (1.39-fold) under $\mathrm{NaCl}$ stress, which shows their ability in alleviating abiotic stress in cucumber in the pot experiments conducted at the Institute of Agricultural Sciences, Banaras Hindu University, Varanasi, India (Pandey et al., 2012). Leite et al. (2014) isolated endophytic and rhizospheric bacteria from the sugarcane's root and rhizosphere respectively in the culture media supplemented with $\mathrm{NaCl}(5 \%)$ and without $\mathrm{NaCl}$ at Pernambuco, Brazil. They investigated the level of salinity tolerance along with the other plant growth promoting traits such as biological nitrogen fixation (BNF), production of indole acetic acid (IAA), inorganic phosphate solubilization, quorum sensing molecule and genetic diversity of isolated endophytic bacteria (Leite et al., 2014).

The accumulation of salts near the root's surface causes toxicity to plant and alter water absorption (Freire \& Freire, 2007). Generally stresses have lethal effects on plant development and growth. Report's of Pandey et al. (2012) suggest that microbial inoculation may recover plant health in stress condition via stimulating plants latent environmental stress response (Pandey et al., 2012).

Bioremediation by bacterial endophyte: Now-adays, excess use of herbicides, insecticides and other synthetic chemicals leads to severe large-scale pollution. With increasing environmental awareness, developing biological strategies using endophytic bacteria are new alternatives for solving such problems. Biore- 
mediation is the use of biological agents to remediate contaminants in the environment or in the other word use of microorganisms to degrade toxins. Phytoremediation is a rapidly expanding field in which plants are used to remediate environmentally toxic compounds. Rhizodegradation, which is a branch of phytoremediation, is the use of plants to stimulate the microbial community near the root-soil interface to enhance the degradation of recalcitrant compounds in the soil. Plants can enhance the bioavailability of soil contaminants by releasing the low molecular weight organic acids, they release carbon and nitrogen containing compounds to nurture root associated microbes and secreted exudates which can enhance the degradation of soil contaminants through inducing biochemical pathways inside the endophytic bacteria (Leigh et al., 2002; White et al., 2003; Newman and Reynolds, 2005).

Endophytic bacteria Methylobacterium populum sp. nov., strain BJ001 is involved in the degradation of 2,4,6 trinitrotoluene (TNT), hexahydro-1,3,5-trinitro1,3,5-triazine (HMX) and hexahydro-1,3,5-trinitro1,3,5-triazine (RDX) (Van Aken et al., 2004a; 2004b). Toluene is hazardous and affects the physiological process. When inhaled at high levels can cause unconsciousness or even death in humans. It is also harmful to plant (Newman and Reynolds, 2005). Van der Lelie's (2005) group has developed a method for genetically endowing a plant endophyte with the ability to degrade toluene (Barac et al., 2004; Newman and Reynolds, 2005). Burkholderia cepacia is having ability to grow in the presence of elevated levels of toluene and degrade it. The natural ability of endophyte to degrade xenobiotics is being investigated with regard to improving phytoremediation (Siciliano et al., 2001; Barac et al., 2004; Germaine et al., 2004; 2006; Porteous-Moore et al., 2006; Ryan et al., 2008).

\section{Conclusion}

It is concluded that the endophytic bacteria must be used to ameliorate the abiotic stresses arising due to variable environmental conditions, physiological alteration inside the plants and adverse effect of synthetic fertilizers and pesticides. The endophytic bacteria have ability to produce several kinds of novel bioactive compounds and metabolites which can be able to positively regulate the physiological disorder inside the plants. Their efficiency has been realized as they have a rapid multiplication cycle, have wider adaptability to variable and changing environment, have fast responses in induction of host immune defense. They provide an insight towards the alternatives for the sustainable and protected cultivation in progressive agriculture. Bioremediation by employing endophytic bacteria to remediate toxic recalcitrant residues of herbicides, insecticides and synthetic chemicals along with excess heavy metals which is toxic to plants is an emerging field of research. Further, studies of endo- phytic bacteria will offer a better understanding of their association with the host plant and provides a new finding in the endophytic research.

\section{ACKNOWLEDGEMENTS}

Authors are grateful to the Department of Biotechnology (DBT), Govt. of India for the Project Establishment of Institutional Biotechnology Hub.

\section{References}

Andrews, J.H. (1992). Biological control in the phyllosphere. Annu. Rev. Phytopathol., 30: 603-635

Anu Ranjan, S. (2012). Microbial endophytes of crop plants and their role in plant growth promotion. Ph. D., Thesis, University of Agricultural Sciences, Bangalore, India.

Bacilio-JimeÂnez, M., Aguilar-Flores, S., del Valle, M.V., PeÂrez, A., Zepeda, A. and Zenteno, E. (2001). Endophytic bacteria in rice seeds inhibit early colonization of roots by Azospirillum brasilense. Soil Biol. Biochem., 33: $167-172$

Barac, T., Taghavi, S., Borremans, B., Provoost, A., Oeyen, L., Colpaert, J.V., Vangronsveld, J. and van der Lelie, D. (2004). Engineered endophytic bacteria improve phyto-remediation of water soluble, volatile, organic pollutants. Nat. Biotechnol. 22: 583-588

Bull, A.T. (Ed). (2004). Microbial diversity and bioprospecting. ASM press.

de Melo, F.M.P., Fiore, M.F., de Moraes, L.A.B., SilvaStenico, M.E., Scramin, S., de Araújo Teixeira, M. and de Melo, I.S. (2009). Antifungal compound produced by the cassava endophyte Bacillus pumilus MAIIIM4A. Sci. Agric. (Piracicaba, Braz.). 66(5): 583-592

Dodd, I.C., Zinovkina, N.Y., Safronova, V.I. and Belimov, A.A. (2010). Rhizobacterial mediation of plant hormone status. Ann. Appl. Biol. 157: 361-379

Dugardeyn, J. and van der Straeten, D. (2008). Ethylene: fine -tuning plant growth and development by stimulation and inhibition of elongation. Plant Sci. 175: 59-70

Elvira-Recuenco, M. and Vuurde, J.W.L.V. (2000). Natural incidence of endophytic bacteria in pea cultivars under field conditions. Can. J. Microbiol. 46: 1036-1041

Foy, C.D. (1988). Plant adaptation to acid aluminium toxic soils. Commun. Soil Sci. Plant Anal. 19: 959-987

Freeman, E.M. (1904). The seed fungus of Lolium temulentum L. Phil. Trans. R. Soc. Lond. (Biol). 196: 1-27

Freire, M.B.G.S. and Freire, F.J. (2007). Fertilidade do solo e seu manejo em solos afetados por sais. In: Fertilidade do Solo. Novais, R.F.; Alvarez V., V.H.; Barros, N.F.; Fontes, R.L. F.; Cantarutti, R.B.; Neves, J.C.L. (ed.). Viçosa: Sociedade Brasileira de Ciência do Solo, p.929-954

Germaine, K., Liu, X., Cabellos, G., Hogan, J., Ryan, D. and Dowling, D.N. (2006). Bacterial endophyte-enhanced phyto-remediation of the organochlorine herbicide 2,4dichlorophenoxyacetic acid. FEMS Microbiol. Ecol. 57: 302-310

Germaine, K., Keogh, E., Garcia-Cabellos, G., Borremans, B., Lelie, D., Barac, T., Oeyen, L., Vangronsveld, J., Moore, F.P., Moore, E.R., Campbell, C.D., Ryan, D. and Dowling, D.N. (2004). Colonisation of poplar trees by gfp expressing bacterial endophytes. FEMS Microbiol. Ecol. 48: 109-118

Glick, B.R. (2005). Modulation of plant ethylene levels by 
the bacterial enzyme ACC deaminase. FEMS Microbiol Lett. 251: 1-7

Grover, M., Ali, S.Z., Sandhya, V., Rasul, A. and Venkateswarlu, B. (2010). Role of microorganisms in adaptation of agriculture crops to abiotic stress. World J. Microbiol. Biotechnol., 27(5): 1231-1240

Hallman, J., Quadt-Hallman, A., Mahafee, W.F. and Kloepper, J.W. (1997). Bacterial endophytes in agricultural crops. Can. J. Microbiol. 43: 895-914

Hawksworth, D.L., Kirk, P.M., Sutton, B.C. and Pegler, D.N. (1995). Ainsworth \& Bisby's dictionary of the fungi, 8th ed. International Mycological Institute, $\mathrm{CAB}$ International, Egham.

James, E.K. and Olivares, F.L. (1998). Infection and colonization of sugarcane and other graminaceous plants by endophytic diazotrophs. Crit. Rev. Plant Sci., 17: 77-119

Jha, Y., Subramanian, R.B. and Patel, S. (2011). Combination of endophytic and rhizospheric plant growth promoting rhizobacteria in Oryza sativa shows higher accumulation of osmoprotectant against saline stress. Acta Physiol. Plant, 33: 797-802

Ji, S.H., Gururani, M.A. and Chun, S.-C. (2014). Isolation and characterization of plant growth promoting endophytic diazotrophic bacteria from Korean rice cultivars. Microbiological research. 169: 83-98

Kelemu, S., Fory, P., Zuleta, C., Ricaurte, J., Rao, I. and Lascano, C. (2011). Detecting bacterial endophytes in tropical grasses of the Brachiaria genus and determining their role in improving plant growth. Afr. J. Biotech. 10(6): 965-976

Kinraide, T.B. (1991). Identity of the rhizotoxic aluminium species. Plant Soil. 134: 167-178

Lambrecht, M., Okon, Y., VandeBroek, A. and Vanderleyden, J. (2000). Indole-3-acetic acid: a reciprocal signalling molecule in bacteria-plant interactions. Trends Microbiol. 8: 298-300

Leigh, M.B., Fletcher, J.S., Fu, X. and Schmitz, F.J. (2002). Root turnover: an important source of microbial substrates in rhizosphere remediation of recalcitrant contaminants. Environ. Sci. Technol. 36: 1579-1583

Leite, M.C.B.S., de Farias, A.R.B., Freire, F.J., Andreote, F.D., Kuklinsky-Sobral, J. and Freire, M.B.G.S. (2014). Isolation, bioprospecting and diversity of salt-tolerant bacteria associated with sugarcane in soils of Pernambuco, Brazil. R. Bras. Eng. Agríc. Ambiental. 18 (Suplemento): S73-S79

Liu, B., Huang, L., Buchenauer, H. and Kang, Z. (2010). Isolation and partial characterization of an antifungal protein from the endophytic Bacillus subtilis strain EDR4. Pest. Bioch. Physiol. 98: 305-311

Lodewyckx, C., Vangronsveld, J., Porteous, F., Moore, E.R.B., Taghavi, S., Mezgeay, M. and Van der Lelie, D. (2002). Endophytic bacteria and their potential applications. Crit. Rev. Plant Sci. 21: 583-606

Metternicht, G.I. and Zinck, J.A. (2003). Remote sensing of soil salinity: potentials and constraints. Remote Sens. Environ. 85: 1-20

Misra, A.K. and Dave, N. (2013). Impact of soil salinity and erosion and its overall impact on India. International Journal of Innovative Research in Engineering \& Science. 2(3): 12-17

Munns, R. and Tester, M. (2008). Mechanisms of salinity tolerance. Annu. Rev. Plant Biol. 59: 651-681
Newman, L. and Reynolds, C. (2005). Bacteria and phytoremediation: new uses for endophytic bacteria in plants. Trends Biotechnol. 23: 6-8

Pandey, P.K., Samanta, R., and Yadav, R.N.S. (2015). Plant Beneficial Endophytic Bacteria from the Ethnomedicinal Mussaenda roxburghii (Akshap) of Eastern Himalayan Province, India. Advances in Biology. 580510, 8

Pandey, P.K., Samanta, R., and Yadav, R.N.S. (2016). Functional attributes of Solanum Kurzii associated bacterial endophytes for plant growth promotion. Asian $J r$. of Microbiol. Biotech. Env. Sc. 18(2): 145-158

Pandey, P.K., Singh, A.K., Singh, S. and Singh, M.C.K. (2013). Recent Advances in Microbiology, Vol- 1, (Eds: Tiwari, S.P., Sharma, R. and Singh, R.K.), Nova Science Publishers, Inc, New York, USA.

Pandey, P.K., Yadav, S.K., Singh, A., Sarma, B.K., Mishra, A. and Singh, H.B. (2012). Cross-Species Alleviation of Biotic and Abiotic Stresses by the Endophyte Pseudomonas aeruginosa PW09. J. Phytopathology. 160: 532-539

Patel, B.B., Patel, B.B. and Dave, R.S. (2011). Studies on infiltration of saline-alkali soils of several parts of Mehsana and Patan districts of north Gujarat. J Appl Technol Environ. Sanitation. 1 (1): 87-92

Pathak, K.V. (2011). Purification and characterization of antifungal compounds produced by banyan endophytic Bacilli. PhD Thesis, Sardar Patel University, Vallabh Vidyanagar, Gujarat, India.

Patten, C.L. and Glick, B.R. (1996). Bacterial biosynthesis of indole-3-acetic acid. Can. J. Microbiol. 42: 207-220

Phillips, L.A., Germida, J.J., Farrell, R.E. and Greer, C.W. (2008). Hydrocarbon degradation potential and activity of endophytic bacteria associated with prairie plants. Soil Biol. Biochem., 40: 3054-3064

Porteous-Moore, F., Barac, T., Borremans, B., Oeyen., L., Vangronsveld, J., van der Lelie, D., Campbell, D. and Moore, E.R.B. (2006). Endophytic bacterial diversity in poplar trees growing on a BTEX-contaminated site: the characterisation of isolates with potential to enhance phytoremediation. Sys. App. Micro. 29: 539-556

Ratul, N., Sharma, G.D. and Barooah, M. (2013). Screening of endophytic bacterial isolates of tea (Camellia sinensis L.) roots for their multiple plant growth promoting activities. IJAEB. 6(2): 211-215

Reinhold-Hurek, B. and Hurek, T. (1998). Life in grasses: diazotrophic endophytes. Trend. Microbiol. 6: 139-144

Rogers, A., Mcdonald, K., Muehlbauer, M.F., Hoffman, A., Koenig, K., Newman, L., Taghavi, S. and Van der Lelie, D. (2012). Inoculation of hybrid poplar with the endophytic bacterium Enterobacter sp. 638 increases biomass but does not impact leaf level physiology. $G C B$ Bioenergy. 4: 364-370

Ryan, R.P., Germaine, K., Franks, A., Ryan, D.J. and Dowling, D.N. (2008). Bacterial endophytes: recent developments and applications. FEMS Microbiol. Lett. 278: $1-9$

Sairam, R.K. and Tyagi, A. (2004). Physiology and molecular biology of salinity stress tolerance in plants. Curr. Sci. 86: 407-420

Shrivastava, P. and Kumar, R. (2015). Soil salinity: A serious environmental issue and plant growth promoting bacteria as one of the tools for its alleviation. Saudi Journal of Biological Sciences. 22: 123-131

Siciliano, S.D.,_Fortin, N., Mihoc, A., Wisse, G., Labelle, 
S., Beaumier, D., Ouellette, D., Roy, R., Whyte, L.G., Banks, M.K., Schwab, P., Lee, K., and Greer, C.W. (2001). Selection of specific endophytic bacterial genotypes by plants in response to soil contamination. Appl. Environ. Microbiol., 67: 2469-2475

Singh, D., Singh, N.P., Chauhan, S.K. and Singh, P. (2011). Developing aluminium-tolerant crop plants using biotechnological tools. Current Science. 100(12): 1807- 1814.

Smyth, E. (2011). Selection and analysis of bacteria on the basis of their ability to promote plant development and growth. PhD Thesis, University College Dublin.

Strobel, G., Daisy, B., Castillo, U. and Harper, J. (2004). Natural products from endophytic microorganisms. $J$. Nat. Prod., 67: 257-268

Sturz, A.V., Christie, B.R. and Nowak, J. (2000). Bacterial endophytes: potential role in developing sustainable systems of crop production. Crit. Rev. Plant Sci. 19: 1-30

Sun, L.N., Zhang, Y.F., He, L.Y., Chen, Z.J., Wang, Q.Y., Qian, M. and Sheng, X.F. (2010). Genetic diversity and characterization of heavy metal-resistant-endophytic bacteria from two copper tolerant plant species on copper mine wasteland. Bioresour. Technol., 101: 501-509

Suto, M., Takebayashi, M., Saito, K., Tanaka, M., Yokota, A. and Tomita, F. (2002). Endophytes as producers of xylanase. Journal of bioscience and bioengineering, 93 (1): $88-90$

Van Aken, B., Peres, C.M., Doty, S.L., Yoon, J.M. and Schnoor, J.L. (2004a). Methylobacterium populum sp. nov., a novel aerobic, pink-pigmented, facultatively methylotrophic, methane-utilizing bacterium isolated from poplar trees (Populus deltoides x nigra DN34). Int. J. Syst. Evol. Microbiol., 54: 1191-1196

Van Aken, B., Yoon, J.M. and Schnoor, J.L. (2004b). Biodegradation of nitro-substituted explosives 2,4,6Trinitrotoluene, Hexahydro-1,3,5-Trinitro-1,3,5- Triazine, and Octahydro-1,3,5,7-Tetranitro-1,3,5-Tetrazocine by a phytosymbiotic Methylobacterium sp. associated with Poplar Tissues (Populus deltoids x nigra DN34). Appl. Environ. Microbiol., 70: 508-517

van der Lelie, D., Barac, T., Taghavi, S. and Vangronsveld, J. (2005). Response to Newman: New uses of endophytic bacteria to improve phytoremediation. TRENDS in Biotechnology, 23: 1 .

Verma, S.C., Ladha, J.K. and Tripathi, A.K. (2001). Evaluation of plant growth promoting and colonization ability of endophytic diazotrophs from deep water rice. $\mathrm{J}$. Biotechnol. 91: 127-141

Vogl, A.E. (1898). Mehl und die anderen mehlprodukte der cerealien und leguminosen. Nahrungsm Unters Hyg Warenk 12: 25-29

Wang, H., Wen, K., Zhao, X., Wang, X., Li, A. and Hong, H. (2009). The inhibitory activity of endophytic Bacillus sp. strain CHM1 against plant Pathogenic fungi and its plant growth-promoting effect. Crop Prot. 28: 634 - 639

White, J.C., Wang, X., Gent, M.P., Iannucci-Berger, W., Eitzer, B.D., Schultes, N.P., et al., (2003). Subspecieslevel variation in the phytoextraction of weathered p,p'DDE by Cucurbita pepo. Environ. Sci. Technol. 37: $4368-4373$

Yensen, N.P. (2008). Halophyte uses for the twenty-first century. In: Khan, M.A. and Weber, D.J. (Eds.), Ecophysiology of High Salinity Tolerant Plants. Springer, Dordrecht, 367-396

Zhu, J.K. (2000). Over expression of a delta-pyrroline-5carboxylate synthetase gene and analysis of tolerance to water and salt stress in transgenic rice. Trends Plant Sci. 6: 66-72

Zinniel, D.K., Lambrecht, P., Harris, N.B., Feng, Z., Kuczmarski, D., Higley, P., Ishimaru, C.A., Arunakumari, A., Barletta, R.G. and Vidaver, A.K. (2002). Isolation and characterization of endophytic colonizing bacteria from agronomic crops and prairie plants. Appl. Env. Microbiol., 68: 2198-2208 